\title{
Stream Drainage Areas in West Virginia
}

U.S. Department of the Interior-U.S. Geological Survey

Cooperative programs among the U.S. Geological Survey (USGS), West Virginia State agencies, and other Federal agencies have accomplished a long-term goal of determining and publishing drainage areas for the entire State. The data are compiled in a series of U.S. Geological Survey Open-File Reports.

The State was divided into seven regions following River Basin boundaries (fig. 1). Separate drainage-area reports were prepared for each region. Report data include stream name; the geographical limits, in river miles; the latitude and longitude at the point of drainage-area determination; the county name; the USGS $7 \frac{1}{2}$ - minute quadrangle in which the point of drainage-area determination lies; and the drainage area at the point of drainage-area determination, in square miles.

\section{Cooperative Programs}

Several State and Federal agencies have cooperated to tabulate drainage areas for streams in West Virginia over the past 20 years.

The first region report and a vision for future programs were established by a cooperative effort between the USGS and the West Virginia Office of Federal-State Relations (reorganized to the Office of Economic and Community Development) in the mid-1970's. "Drainage Areas of the Guyandotte River Basin," was published in September 1977.

Cooperative programs among the USGS; U.S. Army Corp of Engineers, Huntington District; West Virginia Geologic and Economic Survey; West Virginia Department of Natural Resources, Water Resources Division (reorganized to Division of Environmental Protection, Office of Water Resources); and the West Virginia Department of Highways (reorganized to Department of Transportation, Division of Highways) completed the vision by publishing reports for the remaining regions. "Drainage Areas of West Virginia Streams Tributary to the Ohio River," the last region, was published in 1997.

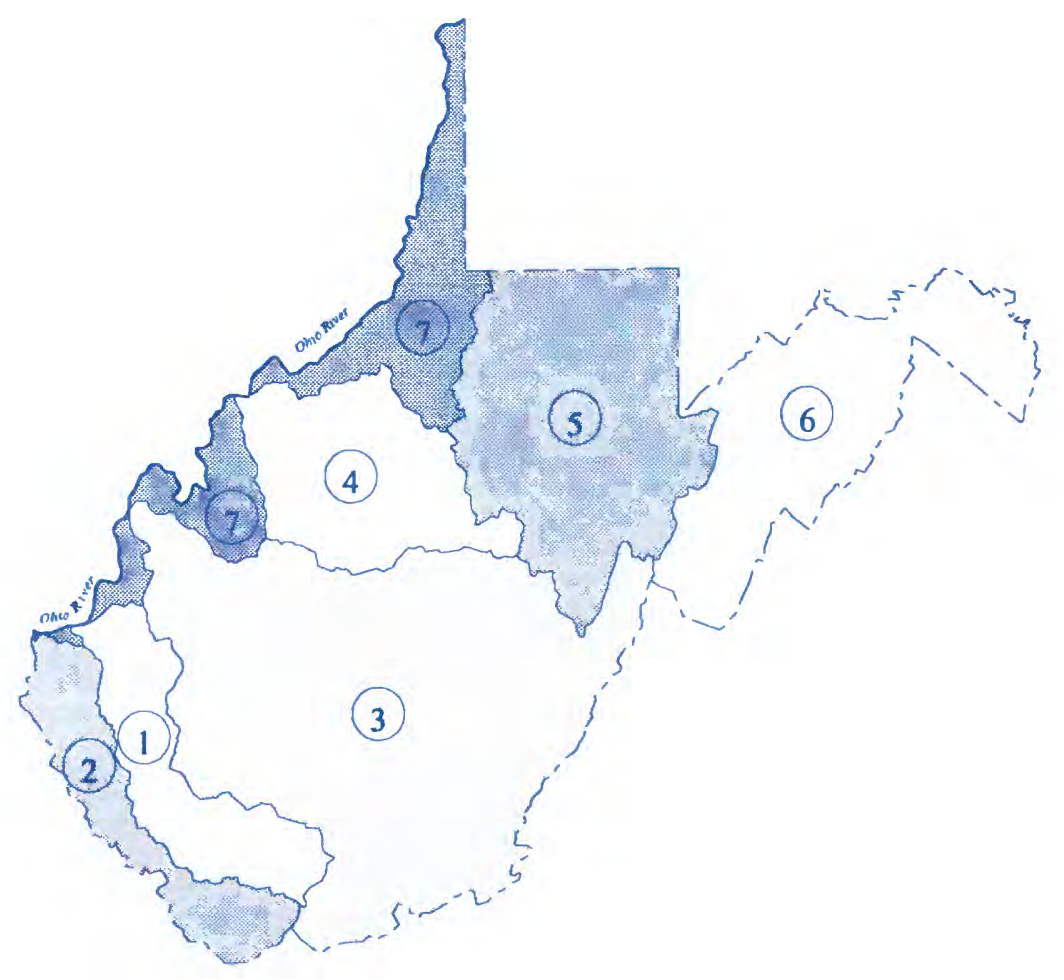

\begin{tabular}{cl}
\hline $\begin{array}{l}\text { Region } \\
\text { number }\end{array}$ & $\begin{array}{l}\text { Region name and } \\
\text { Open-File Report number }\end{array}$ \\
\hline 1 & $\begin{array}{l}\text { Guyandotte River Basin, } \\
\text { USGS Open-File Report 77-801 }\end{array}$ \\
2 & $\begin{array}{l}\text { Twelvepole, Tug, and Big Sandy } \\
\text { River Basins, }\end{array}$ \\
& $\begin{array}{l}\text { USGS Open-File Report 79-746 } \\
\text { Kanawha River Basin, } \\
\text { USGS Open-File Report 82-351 }\end{array}$ \\
4 & $\begin{array}{l}\text { Little Kanawha River Basin, } \\
\text { USGS Open-File Report 84-861 }\end{array}$ \\
& $\begin{array}{l}\text { Monongahela River Basin, } \\
\text { USGS Open-File Report 95-170 }\end{array}$ \\
5 & $\begin{array}{l}\text { Potomac River Basin, } \\
\text { USGS Open-File Report 95-292 }\end{array}$ \\
6 & $\begin{array}{l}\text { Streams Tributary to the } \\
\text { Ohio River, } \\
\text { USGS Open-File Report 97-231 }\end{array}$ \\
&
\end{tabular}

Figure 1. Drainage-area report regions. 
Calculation Methods

The River Basin boundaries were outlined on USGS $7^{1} / 2$-minute topographic quadrangles along divides indicated by elevation contours. Drainage boundaries were then traced for tributaries within the River Basin boundaries having drainage areas of approximately 2 to 5 square miles or larger. The drainage areas, stream miles, latitudes, and longitudes of the divisions were determined with an electronic digitizer or calculated by application of a geographic information system. The area in each quadrangle was measured and compared with the areas of quadrilaterals of the Earth's surface of $7 \frac{1}{2}$-minutes in latitude and longitude, found in the "Inter-Agency Coordination of Drainage Area Data" (1951). The total calculated areas were then adjusted to agree with the total area of the $7 \frac{1}{2}$-minute topographic quadrangles. Drainage areas are accumulated and are accurate to three significant figures, although some areas are reported to greater than three significant figures for accounting purposes. River miles were measured from the stream mouth to the point of drainage-area determination and reported to the nearest one-tenth of a mile for the tributary streams. Previously established river miles presented on the USGS $7 \frac{1}{2}-$ minute topographic quadrangles were reported for the Ohio River main stem. The latitude and longitude at the point of drainage-area determination were reported to the nearest second.

\section{Uses of Drainage Areas}

In many regression equations developed for hydraulic assessments, drainage area is used as an independent variable. Drainage area was determined to be the most significant independent variable in USGS studies that developed equations for estimating low flows (Friel and others, 1989), peak discharges (Runner, 1980), and peak stages (Wiley, 1987). These equations are used by resource managers and governmental agencies to assist in regulating effluents, designing bridges and culverts, and determining the magnitude and extent of flooding.

\section{Drainage-Area Reports}

Seven USGS Open-File Reports describe the areas of the seven regions shown in figure 1. These reports, in the order of publication date, are listed below.

\section{Region \\ number USGS Open-File Report \\ 1 Mathes, M.V, Jr., 1977, Drainage areas of the Guyandotte River Basin, West Virginia: U.S. Geological Survey Open-File Report 77-801, 56 p.}

Wilson, M.W., 1979, Drainage areas of the Twelvepole Creek Basin, West Virginia; Big Sandy River Basin, West Virginia; Tug Fork Basin, Virginia, Kentucky, West Virginia: U.S. Geological Survey OpenFile Report 79-746, 49 p.

Mathes, M.V., Kirby, J.R., Payne, D.D., and Shultz, R.A., 1982, Drainage areas of the Kanawha River Basin, West Virginia: U.S. Geological Survey OpenFile Report 82-351, 222 p.

Preston, J.S., and Mathes, M.V., 1984, Stream drainage areas for the Little Kanawha River Basin, West Virginia: U.S. Geological Survey Open-File Report 84-861, 171 p.

Stewart, D.K., and Mathes, M.V., 1995, Drainage areas of the Monongahela River Basin, West Virginia: U.S. Geological Survey Open-File Report 95170, 79 p.

Wiley, J.B., and Hunt, M.L., 1995, Drainage areas of the Potomac River Basin, West Virginia: U.S. Geological Survey OpenFile Report 95-292, 60 p.

Wiley, J.B., 1997, Drainage areas of West Virginia streams tributary to the Ohio River: U.S. Geological Survey Open-File Report 97-231, 70 p.
These reports are available at many public libraries and are available for viewing at the USGS West Virginia District office (address given below). Paper or microfiche copies of the reports can be ordered from:

U.S. Geological Survey

Branch of Information Services

Box 25286

Denver, Colorado 80225-0286

(303) 202-4210

—Jeffrey B. Wiley

\section{References Cited}

U.S. Geological Survey, 1951, Interagency Coordination of Drainage Area Data: Notes on Hydrologic Activities, Bulletin 4, 48 p.

Friel, E.A., Embree, W.N., Jack, A.R., and Atkins, J.T., Jr., 1989, Low-flow characteristics of streams in West Virginia: U.S. Geological Survey WaterResources Investigations Report 88-4072, $34 \mathrm{p}$.

Runner, G.S., 1980, Runoff studies on small drainage areas: U.S. Geological Survey Open-File Report 80-1218, 44 p.

Wiley, J.B., 1987, Techniques for estimating flood-depth frequency relations for streams in West Virginia: U.S. Geological Survey Water-Resources Investigations Report 87-4111, $17 \mathrm{p}$.

\section{Additional information on drainage areas in West Virginia can be obtained from:}

District Chief

U.S. Geological Survey

11 Dunbar Street

Charleston, WV 25301

(304) $347-5130$ 